\title{
Susceptibility to drug-induced apoptosis correlates with differential modulation of Bad, Bcl-2 and $\mathrm{Bcl}-\mathrm{x}_{\mathrm{L}}$ protein levels
}

\author{
G Tudor*,1, A Aguilera', DO Halverson ${ }^{1}$, ND Laing ${ }^{1}$ and \\ EA Sausville ${ }^{2}$ \\ ${ }^{1}$ Science Applications International Corporation, National Cancer Institute - \\ Frederick Cancer Resource and Development Center, Frederick, P.O. Box B \\ Maryland, MD 21702, USA \\ 2 Developmental Therapeutics Program, Division of Cancer Treatment, National \\ Cancer Institute, EPN-843, 6130 Executive Blvd., Rockville, Maryland MD \\ 20892-7446, USA \\ * Corresponding author: G Tudor, Science Applications International \\ Corporation, NCl - FCRDC, P.0. Box B, Frederick, Maryland, MD 21702, USA \\ Tel: (301)-846-5127; Fax: (301)-846-5304; E-mail: tudor@dtpax2.ncifcrf.gov
}

Received 30.7.99; revised 5.2.00; accepted 6.3.00

Edited by JC Reed

\begin{abstract}
To define the responses of apoptotic regulatory proteins to different chemotherapeutic agents, we investigated the expression of $\mathrm{Bcl}-2$ family gene products, the release of cytochrome $c$, and the activation of pro-caspase-3 during apoptosis induced by Taxol and Thiotepa, in the MCF-7 breast carcinoma and the HL-60 leukemia cell lines. The earliest event induced by drug exposure was increase in Bad protein levels, followed by Bcl-2 down-regulation, cytochrome c release, and $\mathrm{Bcl}-\mathrm{x}_{\mathrm{L}}$ and $\mathrm{Bax}$ up-regulation. Bak accumulation was a late event. Activation of pro-caspase-3 and cleavage of Bcl-2 protein occurred in the HL-60 cells only, and followed the cytochrome $c$ release. The overall responses were qualitatively similar in both cell types, but MCF-7 cells treated with Taxol showed a significant delay in apoptosis, correlating with early up-regulation of $\mathrm{Bcl}-2$ and delayed release of cytochrome $c$. We conclude that Bad up-regulation is an early indicator of a cellular response that will lead to cell death, but may be modulated by survival mechanisms, which cumulatively govern the ultimate susceptibility to apoptosis. Cell Death and Differentiation (2000) 7, 574-586.
\end{abstract}

Keywords: apoptosis; taxol (paclitaxel); thiotepa; Bad; Bcl-2; Bcl-2 cleavage; $\mathrm{Bcl}-\mathrm{x}_{\mathrm{L}}$

\section{Introduction}

Apoptosis is a highly regulated process that results physiologically in the selective death of cells. The cell death pathway may be conceived as a series of intracellular decision points where death regulatory genes are activated in response to physiologic or pathologic signals. The Bcl-2 family of genes is a major component of this pathway, comprising both positive and negative regulators of cell death, which share conserved $\mathrm{Bcl}-2$ homology domains and interact with each other to form a dynamic equilibrium of homo- and hetero-dimers. The intracellular level and the ratio of members of the family dictate the efficiency of engagement in the apoptotic program. ${ }^{1}$

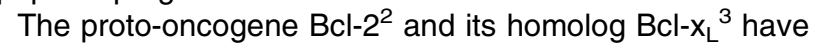
the ability to inhibit apoptosis induced by a variety of stimuli, but the biochemical mechanism of their function is continuing to be elicited. Bcl-2 is an integral membrane protein located on the outer membrane of mitochondria and other organelles. ${ }^{2,4}$ The $\mathrm{Bcl}-\mathrm{x}$ gene generates two alternatively spliced transcripts: $\mathrm{Bcl}-\mathrm{x}_{\mathrm{L}}$, known to promote survival and the shorter $\mathrm{Bcl}-\mathrm{x}_{\mathrm{S}}$, which antagonizes the $\mathrm{Bcl}-2$ effect. ${ }^{5} \mathrm{BCl}-\mathrm{X}_{\mathrm{L}}$ is an integral membrane protein, again predominantly localized to mitochondria. ${ }^{6}$ Low basal levels of $\mathrm{Bcl}-\mathrm{x}_{\mathrm{L}}$ correlated with a greater tendency to undergo apoptosis, while cells with higher basal levels of $\mathrm{Bcl}-\mathrm{x}_{\mathrm{L}}$ correlated with resistance to apoptosis. ${ }^{7} \mathrm{Bcl}-2$ and $\mathrm{Bcl}-\mathrm{x}_{\mathrm{L}}$ tend to prevent the loss of membrane potential, the efflux of cytochrome $c$ from the mitochondria and the initiation of apoptosis. $^{8-10}$

Bad, a Bcl-2 related family member, promotes cell death apparently by hetero-dimerization with $\mathrm{Bcl}-2$ or $\mathrm{Bcl}-\mathrm{x}_{\mathrm{L}}$ death antagonists, which eventually results in the release of free Bax and apoptosis. ${ }^{11,12}$ Bad can be phosphorylated by the serine/threonine kinase Akt (and other kinases), and in the phosphorylated state binds to 14.3.3 proteins in the cytosol and only the unphosphorylated form binds to the Bcl- $\mathrm{X}_{\mathrm{L}}$ at membrane sites. ${ }^{13,14}$

$\mathrm{Bak}^{15}$ and Bax, ${ }^{16}$ two other members of the Bcl-2 family, have been shown to accelerate apoptosis. Bax protein can induce both membrane potential dissipation and cytochrome $c$ release, suggesting that Bax acts to destabilize mitochondrial membrane function. ${ }^{17,18}$ Suppression of survival signals is the result of complex formation between $\mathrm{Bcl}-2$ or $\mathrm{Bcl}-\mathrm{x}_{\mathrm{L}}$ and apoptosis inducing proteins like Bax and $\mathrm{Bak}^{5,19}$ where a high $\mathrm{Bcl}-2 / \mathrm{Bax}$ ratio favors cell survival whereas a low ratio promotes apoptosis. ${ }^{20}$

Post-translational modifications of $\mathrm{Bcl}-2$ have also been proposed as a regulatory mechanism of apoptosis. Phosphorylation of $\mathrm{Bcl}-2$ has been reported, although it is still unclear whether $\mathrm{Bcl}-2$ phosphorylation is activating or inactivating ${ }^{21-24}$ and whether this is a general phenomenon since it appears to occur prominently in M-phase arrested cells $^{25,26}$ More recently, Bcl-2 was reported to be a substrate for cleavage by activated caspase-3 with the carboxylterminal $\mathrm{Bcl}-2$ cleavage product triggering apoptosis. ${ }^{27}$

Apoptotic pathways activated by various signals, converge into a common event controlled by the ICE family proteases or caspases, which are antagonized by the anti-apoptotic members of the Bcl-2 family. ${ }^{28}$ Caspases are present in the cytosol as inactive precursors and cleaved to an active form during apoptosis. ${ }^{29}$ The mammalian caspase- 3 plays a critical role in the apoptotic 
pathway, and cytochrome $c$ is necessary for its activation through a complex formation with Apaf-1 and caspase- $9 .^{30}$

A key question, which we address in this paper, is how chemotherapeutic agents with diverse molecular targets interact with the bcl-2 family-regulated survival system. Thiotepa is a classical DNA directed alkylating agent ${ }^{31,32}$ currently used in 'high dose' therapy approaches to the treatment of both hematopoietic and solid tumors. Thiotepa induces S-phase cell cycle arrest and cell death as a result of DNA cross-links or adducts formation. Taxol (paclitaxel) has demonstrated a broad spectrum of activity against both solid tumor and leukemia cell lines and it is established that it binds to and stabilizes the microtubules, which results in mitotic disruption and subsequent block in G2/M. ${ }^{33-38}$ The lag between mitotic block and cell death varies depending on the cell line. The signal transduction pathways involved in cell cycle arrest and apoptosis induced by Taxol continue to be subject of investigation. ${ }^{39-44}$

In the present study, we show that HL-60 cells respond to Taxol and Thiotepa treatment by showing early initiation of apoptosis. In contrast, MCF-7 cells show delayed apoptosis in response to Taxol but not to Thiotepa. Despite these differences in time course, the two cell lines show qualitatively very similar patterns of apoptotic regulation in response to the two drugs. The efficiency and timing of apoptosis depend on the degree to which cytochrome c release occurs. We detect Bad up-regulation as an early response to drug treatment, which precedes the release of cytochrome $c$ into the cytosol in both $\mathrm{HL}-60$ and MCF-7 cells. We also detect an early increase in Bad protein levels in different other cell lines belonging to the leukemia/lymphoma and breast sub-panels, and certain lung carcinoma cells from the $\mathrm{NCl}$ in vitro drug screen. The release of cytochrome $\mathrm{c}$ is greatly delayed in the MCF-7 cells in response to Taxol but not to Thiotepa, and in comparison to the HL-60 cells. This delay correlates with the up-regulation of $\mathrm{Bcl}-2$. Activation of pro-caspase-3 occurs after cytochrome c release in the HL-60 cells. Bad and Bax down-regulation and accumulation of Bak are late events, occurring in the context of increasing cell death. Our results suggest that in response to drug treatment, cells can undergo delayed or accelerated apoptosis based on the differential regulation of $\mathrm{Bad}, \mathrm{Bcl}-2$ and $\mathrm{Bcl}-\mathrm{x}_{\mathrm{L}}$ expression, and underscores the basis for interest in defining therapeutic strategies, which might modulate these targets.

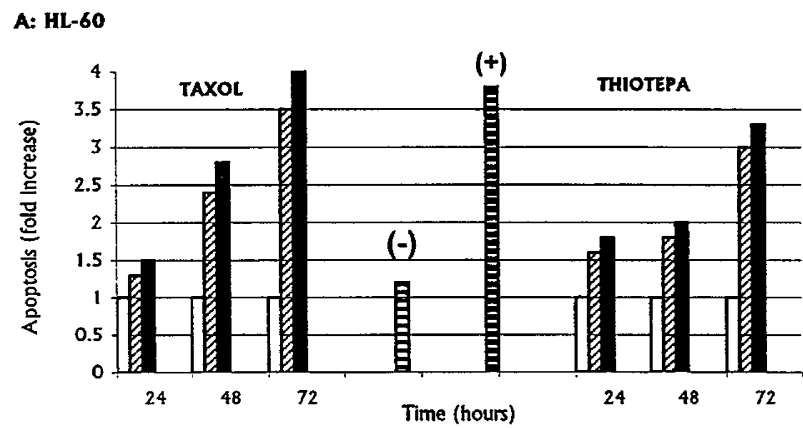

B: MCF-7

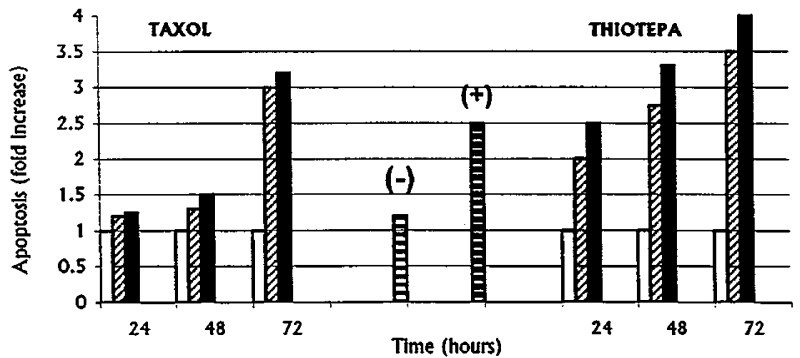

Figure 1 Quantitative ELISA for DNA fragmentation in MCF-7 and HL-60 cells after Taxol and Thiotepa treatment. Fold increase in apoptosis expressed as amount of cytoplasmic DNA-histone in treated cells compared to untreated cells. HL-60 cells (A) and MCF-7 cells (B) were treated with 0 (empty bar), 50 (hatched bar) and 100 (filled bar) nM Taxol or with 0 (empty bar), 100 (hatched bar) and 200 (filled bar) $\mu \mathrm{M}$ Thiotepa, in a 96-well plate. Cytoplasmic extracts were prepared after $0,24,48$ and $72 \mathrm{~h}$ of drug treatment, according to the manufacture's instructions (Cell Death ELISA, Boehringer Manheim, Indianapolis, IN, USA). Positive controls for apoptosis (+) were HL-60 cells treated with $150 \mathrm{nM}$ Camtothecin for $4 \mathrm{~h}(\mathbf{A})$ and MCF-7 cells treated with $10 \mu \mathrm{M}$ Calcium lonophore A 23187 for $24 \mathrm{~h}$ (B). The control for nectotic death (-) consisted of HL-60 and MCF-7 cells treated with $20 \mathrm{mM} \mathrm{KCN}$ for $4 \mathrm{~h}$, as described elsewhere. ${ }^{8}$ The enrichment of nucleosomes in the cytoplasm of treated cells is expressed as fold increase, compared to untreated cells. Each treatment was performed in triplicate and the results shown are representative of three separate experiments (standard deviation was less than $5 \%$ )

Table 1

\begin{tabular}{|c|c|c|c|c|c|c|c|}
\hline \multicolumn{8}{|c|}{ (A) Basal levels of expression of Bcl-2 family members, capase-3 and p53 status } \\
\hline Cell line & BAD $^{\mathrm{a}}$ & BCL-2 ${ }^{a}$ & $B C L-x L^{a}$ & BAX $^{a}$ & BAK $^{\mathrm{a}}$ & Capase-3 & $\mathbf{P} 53^{\mathrm{b}}$ \\
\hline $\begin{array}{l}\mathrm{HL}-60 \\
\text { MCF-7 }\end{array}$ & $\begin{array}{r}0 \\
14\end{array}$ & $\begin{array}{l}16 \\
11\end{array}$ & $\begin{array}{r}2 \\
16\end{array}$ & $\begin{array}{l}10 \\
13\end{array}$ & $\begin{array}{l}18 \\
21\end{array}$ & $\begin{array}{l}+ \\
-\end{array}$ & $\begin{array}{l}-1- \\
w / w\end{array}$ \\
\hline \multicolumn{8}{|c|}{ (B) Cytotoxicity of Taxol and Thiotepa } \\
\hline & & Taxol & & & Thiotepa & & \\
\hline Cell line & GI50 & TGI & LC50 & GI50 & TGI & LC50 & \\
\hline $\begin{array}{l}\text { HL-60 } \\
\text { MCF-7 }\end{array}$ & $\begin{array}{l}0.005 \\
0.005\end{array}$ & $\begin{array}{c}0.05 \\
0.5-1\end{array}$ & $\begin{array}{l}0.5-1 \\
50-100\end{array}$ & $\begin{array}{l}10 \\
30\end{array}$ & $\begin{array}{l}200 \\
300\end{array}$ & $\begin{array}{l}\leqslant 500 \\
\leqslant 500\end{array}$ & \\
\hline
\end{tabular}

$1 \mathrm{~A}-\mathrm{l}=$ =null, w/w-wild-type. Summary of basal levels of apoptosis-regulating proteins and other targets from the molecular targets database at NCl. ${ }^{\mathrm{a}}$ Determined by relative expression in Immunoblots as $\mathrm{ng} / 50 \mu \mathrm{g}$ of total protein. ${ }^{57}$ betermined through complete bi-directional p53 cDNA sequencing. ${ }^{58} 1 \mathrm{~B}$ Average $\mu \mathrm{M}$ concentrations necessary to induce: GI50 (50\% cell growth inhibition), TGI (total cell growth inhibition) and LC50 (50\% cell death) in a $48 \mathrm{~h}$ cytotoxicity assay as described 59 


\section{Results}

\section{Effects of Taxol and Thiotepa on cell survival and apoptosis}

The HL-60 and the MCF-7 cell lines were selected from the 60 -cell line panel of the $\mathrm{NCl}$ anticancer drug screen. These cells were chosen in an effort to highlight differences in potential apoptotic protein modulation in response to drug action. HL-60 is a myeloid hematopoietic cell line, while MCF7 is from an epithelial breast cancer. As shown in Table 1A, the HL-60 cells have undetectable basal levels of Bad protein and low levels of $\mathrm{Bcl}-\mathrm{x}_{\mathrm{L}}$ protein while MCF-7 cells have high basal levels of $\mathrm{Bad}$ and $\mathrm{Bcl}-\mathrm{x}_{\mathrm{L}}$. The two cell types have comparable levels of Bcl-2, Bax and Bak. MCF-7 cells have undetectable levels of caspase- 3 protein and have a wt p53 status, while HL-60 cells express caspase- 3 and have a null
A

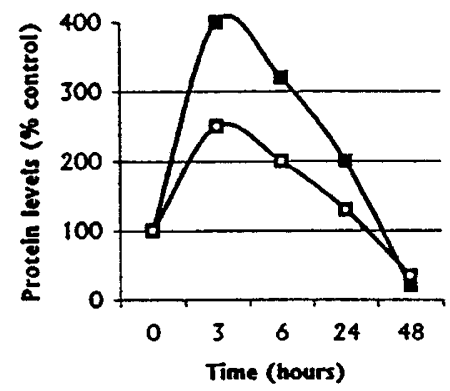

B

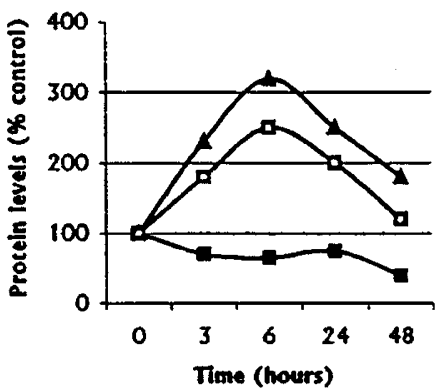

C

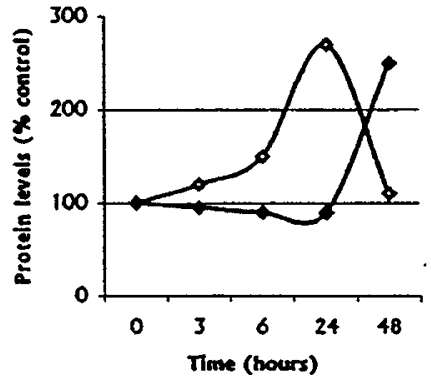

D

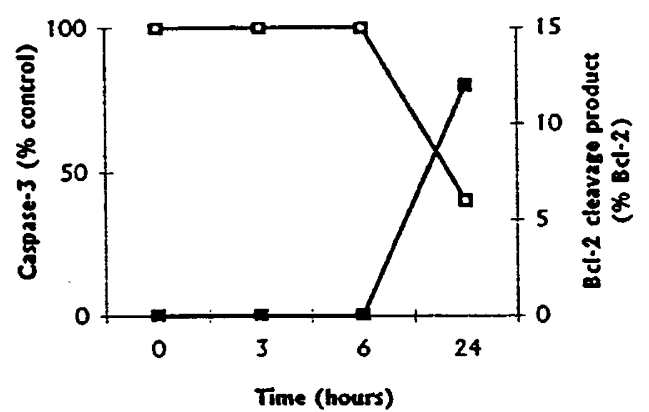

E - HL-60-Taxol

$\rightarrow-10 \mathrm{nM}$ $\rightarrow-50 \mathrm{nM}$

$\rightarrow-100 \mathrm{nM}$

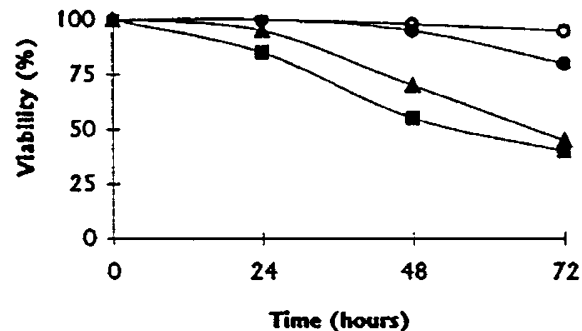

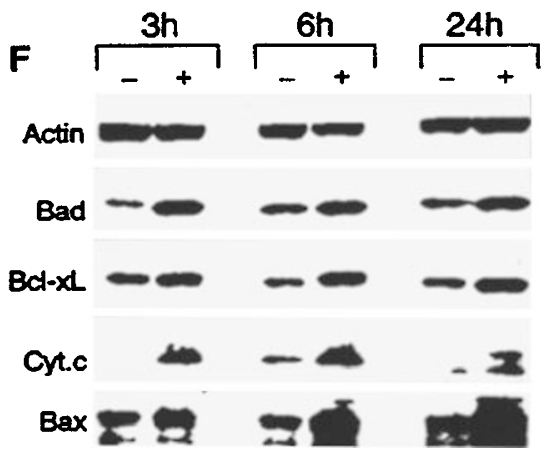
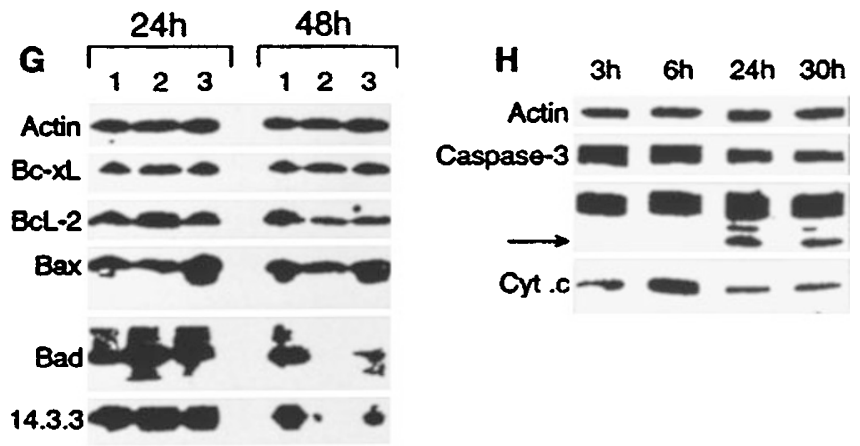

Figure 2 Expression and viability analysis of HL-60 cells treated with Taxol. Total proteins ( $50 \mu \mathrm{g} / \mathrm{lane})$ from HL-60 cells, either treated or not treated with Taxol for $0,3,6,24$ and $48 \mathrm{~h}$, were resolved on $12 \%$ SDS-polyacrylamide gels. The protein levels were assessed by immunoblot analysis with antibodies that detect human Bad, 14.3.3 $\beta, \mathrm{Bcl}-2, \mathrm{Bcl}-\mathrm{x}_{\mathrm{L}}$, Bax, Bak, cytochrome $\mathrm{c}$ and caspase- 3 and measured by densitometric scanning. Anti- $\beta$-actin mAb was used to assess equal protein loading and the relative ratios of 'protein investigated: $\beta$-actin' were calculated by densitometric measurements. Results are expressed as protein levels relative to untreated controls (percentage of control). The results shown are representative of three independent experiments. (A) Bad ( $\square$ ), and 14.3.3 ( $\square$ ) protein levels with

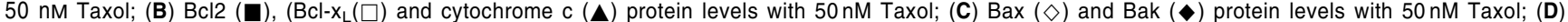
Processing of caspase-3 $(\square)$ at $50 \mathrm{nM}$ Taxol coincides with the appearance of the Bcl-2 cleavage product ( $\mathbf{\square}) ;(\mathbf{E})$ Viability of the HL-60 cells treated with $0,10,50$ and $100 \mathrm{nM}$ Taxol. Cells were collected at intervals, rinsed and scored for viability by Trypan blue staining. Triplicate samples were used for each treatment; (F) Cells were treated with $(+)$ or without $(-) 50 \mathrm{nM}$ Taxol and aliquots, taken at intervals, were analyzed by immunoblot, as described; (G) Cells untreated (lane 1) or treated with $10 \mathrm{nM} \mathrm{Taxol}$ (lane 2) and $50 \mathrm{nM}$ Taxol (lane 3) were analyzed by immunoblot, as described; (H) Cells were treated with $50 \mathrm{nM}$ Taxol and aliquots, taken at intervals, were analyzed by immunoblot, as described. The $(\rightarrow)$ indicates the Bcl-2 cleavage product 
p53. This choice of cells was anticipated to reveal different apoptotic modulatory protein responses to drug. Table 1B shows the cytotoxicity profile for the HL-60 and MCF-7 cells in response to Taxol and Thiotepa. HL-60 cells are more susceptible to Taxol than MCF-7 in screening assays, and both cell types have analogous susceptibility to Thiotepa.

We selected equitoxic concentrations of drug, which completely inhibited cell growth and induced limited cell death at $24 \mathrm{~h}$. This was in an effort to define equivalent degrees of cellular response to the drug, resulting from different ways of potentially modulating responses to apoptotic stimuli. Asynchronous populations of cells were treated with drug for increasing periods of time and evaluated for apoptosis and cell survival, as described in Materials and Methods. Figure 1 shows the fold increases in apoptosis, relative to untreated controls. HL-60 cells, exposed to 50 and $100 \mathrm{nM}$ Taxol (Figure 1A, left), show notable occurrence of apoptosis by $48 \mathrm{~h}$, whereas MCF-7 cells, treated with 100 and $500 \mathrm{nM}$ Taxol (Figure 1B, left), do not display major evidence of apoptosis until $72 \mathrm{~h}$ of drug exposure. In contrast, both cell types show similar patterns of sensitivity to $100-200 \mu \mathrm{M}$ Thiotepa (Figure $1 \mathrm{~A}, \mathrm{~B}$, right), with a $2-3$-fold increase in the proportion of apoptotic cells by $48 \mathrm{~h}$, and $3-3.5$-fold increase in apoptotic cells by $72 \mathrm{~h}$. Noticeably, the MCF-7 cells are more sensitive to Thiotepa than the HL-60 cells.

\section{Expression of apoptotic regulatory proteins, cytochrome $c$ release and activation of pro-caspase- 3 in response to Taxol and Thiotepa}

To study the temporal relationship between protein expression and apoptosis, cells were continuously exposed to drug for different periods of time and analyzed by Western blot and semi-quantitative RT-PCR. The level of expression in parallel cultures, without drug treatment, was considered to be the basal level of expression or $100 \%$ control

The HL-60 cells were treated with 10,50 and $100 \mathrm{nM}$ Taxol and the changes in apoptosis-related protein expression were monitored in an interval between 0 to $48 \mathrm{~h}$. Figure $2(A-D)$ shows these changes in response to $50 \mathrm{nM}$ Taxol, which causes total growth inhibition and 95\% cell survival at $24 \mathrm{~h}$ (Figure $2 \mathrm{E}$ ). In the present study we detect low base-line levels of Bad protein in the HL-60 cells. At $3 \mathrm{~h}$ (Figure 2A,F), there is increased expression of Bad protein (fourfold), accompanied by an increase in 14-33 protein levels and followed by a steady decline. At $48 \mathrm{~h}$, Bad and 14-3-3 protein levels are below baseline levels
A

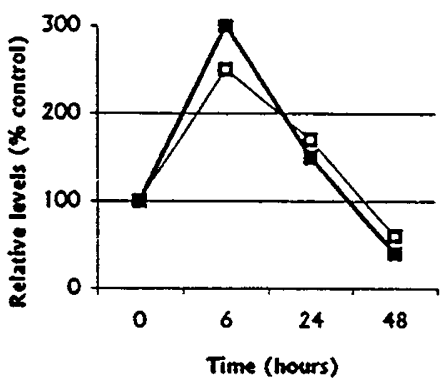

D

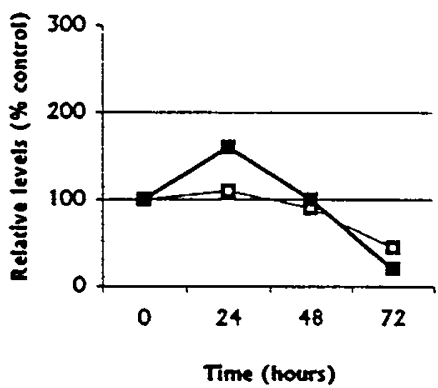

B

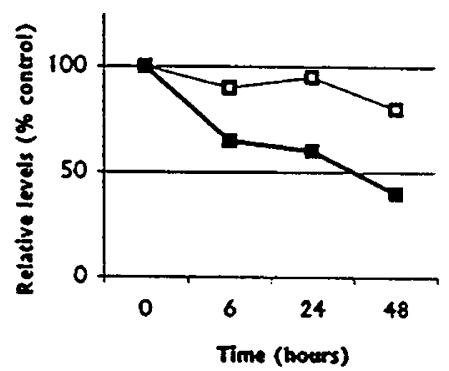

$\mathbf{E}$

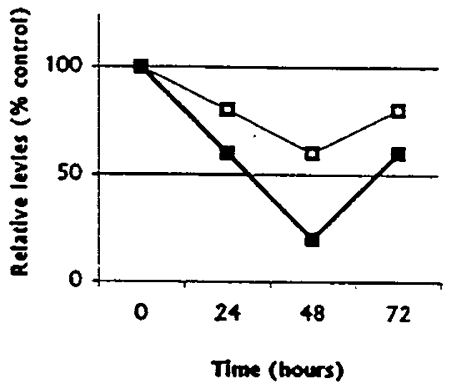

C

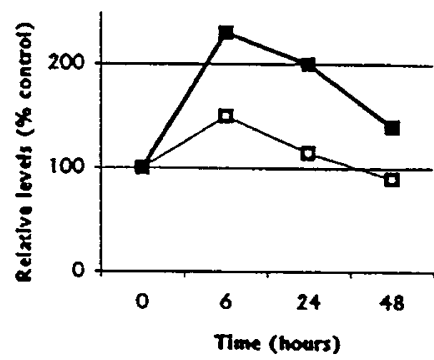

$\mathbf{F}$

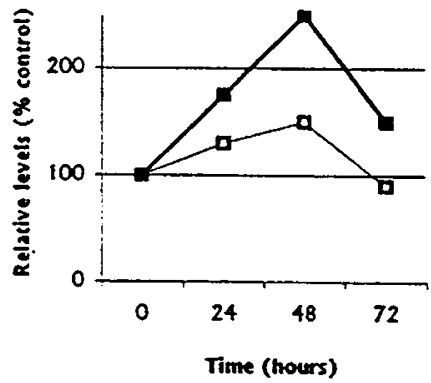

Figure 3 mRNA expression levels in HL-60 and MCF-7 cells treated with Taxol. Total RNA from HL-60 and MCF-7 cells treated with $50 \mathrm{nM}$ and $500 \mathrm{nM}$ Taxol respectively was isolated at different time points, as described. The mRNA levels were assessed by semi-quantitative RT-PCR as described and quantified by densitometric scanning of the amplified products. Results are expressed as mRNA levels relative to untreated controls (percentage of control). The results shown are representative of three independent experiments. (A) Bad mRNA ( $\square$ ) and Bad protein ( $\square$ ) levels in the HL-60 cells; (B) Bcl-2 mRNA ( $\square$ ) and Bcl-2 protein ( $\square$ )

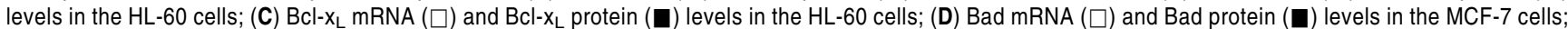

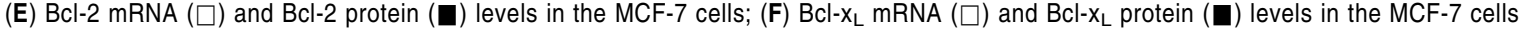


(Figure 2A,G) although, at this point, a notable degree of cell death has occurred. The increase in Bad protein is paralleled by a similar increase in Bad mRNA (Figure 3A), which suggests a transcriptional control of this gene product in response to Taxol treatment. At $3 \mathrm{~h}$ cytochrome $\mathrm{c}$ is being released from the mitochondria and reaches $\mathrm{a}$ peak at $6 \mathrm{~h}$. This is accompanied by the progressive downregulation of $\mathrm{Bcl}-2$ and a steady increase in $\mathrm{Bcl}-\mathrm{x}_{\mathrm{L}}$ protein levels (Figure 2B,F). Bax protein accumulates at $6 \mathrm{~h}$ and reaches a maximal level at $24 \mathrm{~h}$, followed by a drop to base-line levels at $48 \mathrm{~h}$ (Figure 2C,F,G). Bax mRNA levels follow very closely the Bax protein levels. The normalization of Bax levels at $48 \mathrm{~h}$, coincides with accumulation of high levels of Bak protein (Figure 2C) and mRNA. We detected procaspase-3 in the HL-60 lysates as a band at $32 \mathrm{kDa}$, corresponding to the full-length pro-caspase-3. Its activation through cleavage begins after $6 \mathrm{~h}$ (Figure 2D,H) and continues through $48 \mathrm{~h}$. It has been shown that activated caspase-3 initiates the cleavage of $\mathrm{Bcl}-2$ and the generation of a Bcl-2 fragment with apoptotic properties. We notice this $\mathrm{Bcl}-2$ cleavage product being generated at $24 \mathrm{~h}$ (Figure 2D,H), concomitant with caspase-3 activation.
A

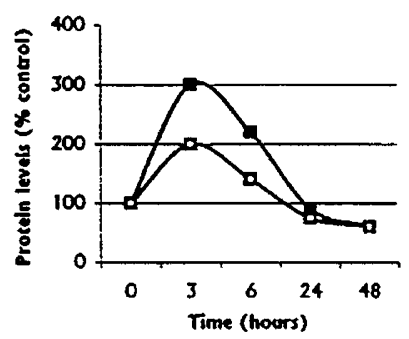

B

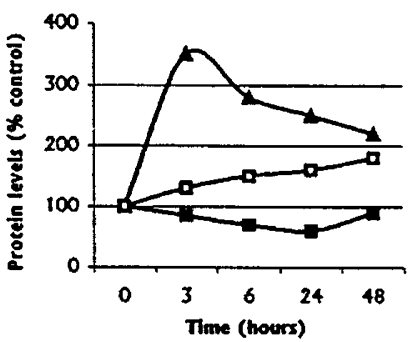

C

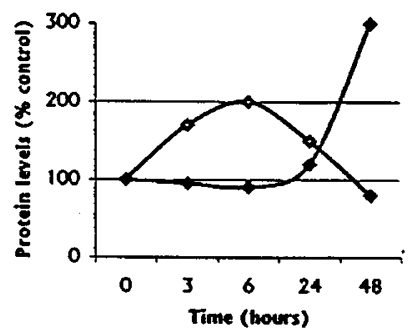

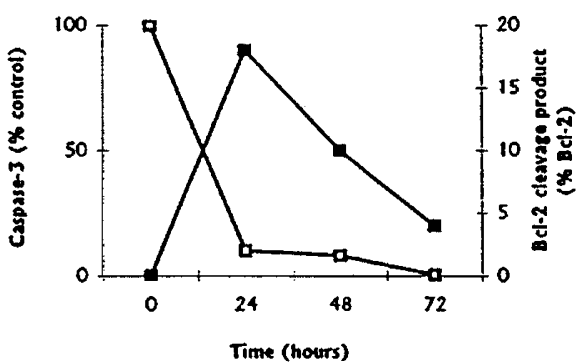

E - HL-60- Thiotepa

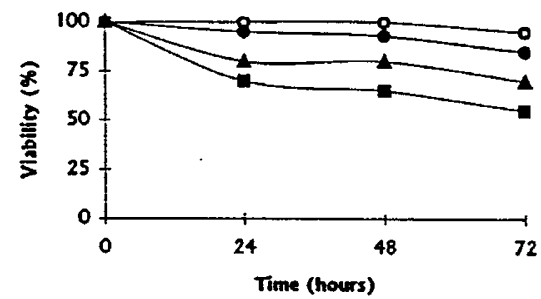

$\mathbf{F}$
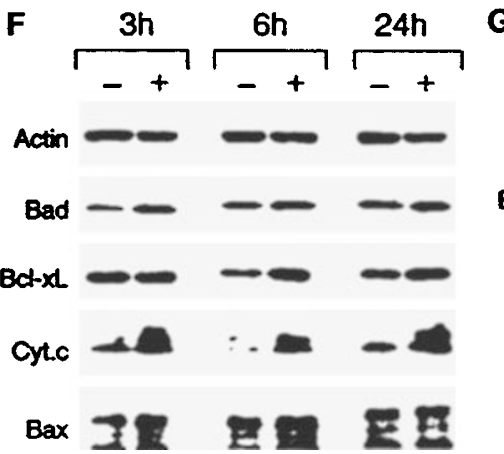

G
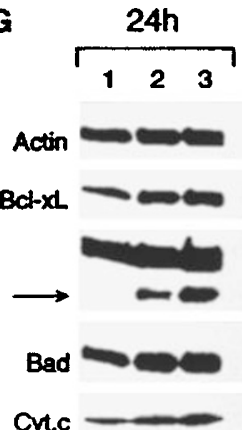

$48 h$

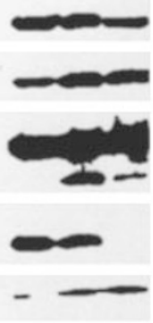

H
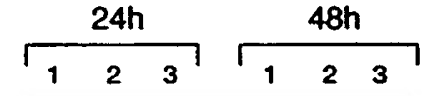

A

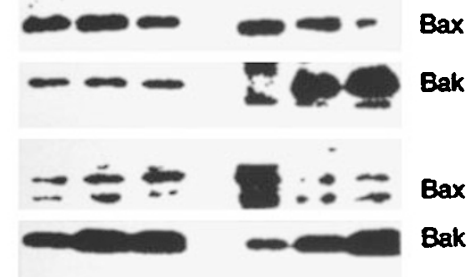

Figure 4 Expression and viability analysis of HL-60 cells treated with Thiotepa. Total proteins $(50 \mu \mathrm{g} / \mathrm{lane})$ from MCF-7 cells, either treated or not treated with Thiotepa for $0,3,6,24$ and $48 \mathrm{~h}$. The overall methodology is similar to Figure 2. The results shown are representative of three independent experiments. (A) Bad

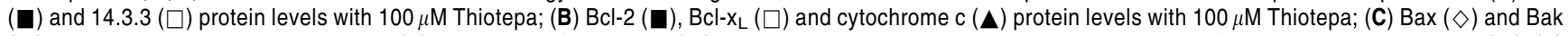
$(\checkmark)$ protein levels with $100 \mu \mathrm{M}$ Thiotepa; (D) Processing of caspase-3 ( $\square$ ) at $100 \mu \mathrm{M}$ Thiotepa coincides with the appearance of the Bcl-2 cleavage product ( $\square$ ); (E) Viability of the HL-60 cells treated with $0,10,100$ and $200 \mu \mathrm{M}$ Thiotepa. Cells were collected at intervals, rinsed and scored for viability by Trypan blue staining. Triplicate samples were used for each treatment; (F) Cells were treated with (+) or without $(-) 100 \mu \mathrm{M}$ Thiotepa and aliquots, taken at intervals, were analyzed by immunoblot, as described; (G) Cells untreated (lane 1) or treated with $100 \mu \mathrm{M}$ (lane 2) or $200 \mu \mathrm{M}$ (lane 3) Thiotepa were analyzed by immunoblot, as described. (H) Row A: Cells untreated (lane 1) or treated with $50 \mathrm{nM}$ Taxol (lane 2) and $100 \mathrm{nM}$ Taxol (lane 3) were analyzed by immunoblot, as described; Row B: Cells untreated (lane 1) or treated with $100 \mu \mathrm{M}$ Thiotepa (lane 2) and $200 \mu \mathrm{M}$ Thiotepa (lane 3) were analyzed by immunoblot, as described 
However, the limited extent of its occurrence $(\leqslant 15 \%$ of the total $\mathrm{Bcl}-2$ protein) is of uncertain significance in affecting the overall $\mathrm{Bcl}-2$ function. The level of phosphorylated $\mathrm{Bcl}-2$ is also high by $24 \mathrm{~h}$ and declines thereafter, but again, its abundance is very limited. These post-translational changes of the Bcl-2 protein could eventually account for its decrease. Alternatively, the reduction in $\mathrm{Bcl}-2$ protein levels and only the limited decrease in mRNA levels (Figure 3B) would suggest post-transcriptional mechanisms, such as inefficient translation or changes in protein stability. The discrepancy between the $\mathrm{Bcl}-\mathrm{x}_{\mathrm{L}}$ protein and $\mathrm{mRNA}$ levels
(Figure $3 \mathrm{C}$ ) could also be due to post-translational changes or to a delay in the $\mathrm{Bcl}-\mathrm{x}_{\mathrm{L}}$ protein synthesis. At $48 \mathrm{~h}$, both survival members $\mathrm{Bcl}-2$ and $\mathrm{Bcl}-\mathrm{x}_{\mathrm{L}}$ are down-regulated, whereas the death inducing protein Bak shows a 2.5-fold increase, which corresponds to high levels of apoptosis (2.5-fold increase).

A similar and more rapid response occurs in the HL-60 cells treated with $100 \mu \mathrm{M}$ Thiotepa (Figure 4), which causes $80 \%$ cell survival at $24 \mathrm{~h}$ (Figure 4E). This is shown by the earlier down-regulation of Bad at $24 \mathrm{~h}$ (Figure 4A,F), the faster increase in cytochrome $c$ release (Figure 4B,F), and
A

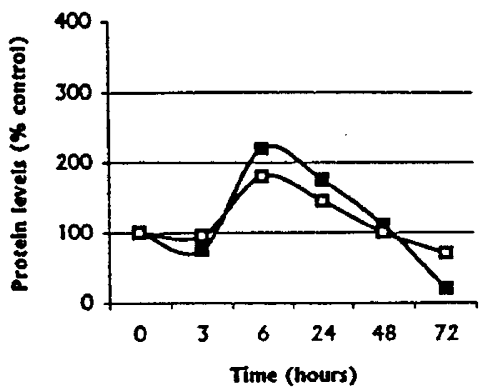

B

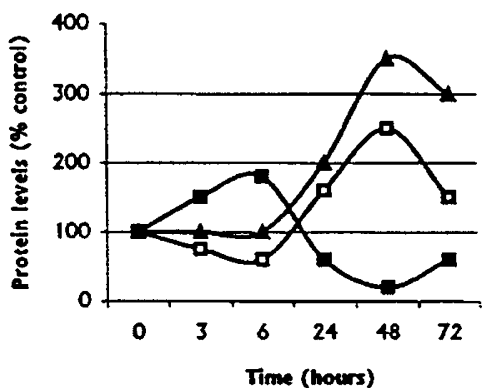

C

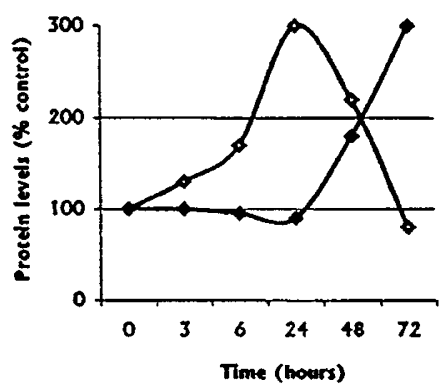

D MCF-7 - Taxol
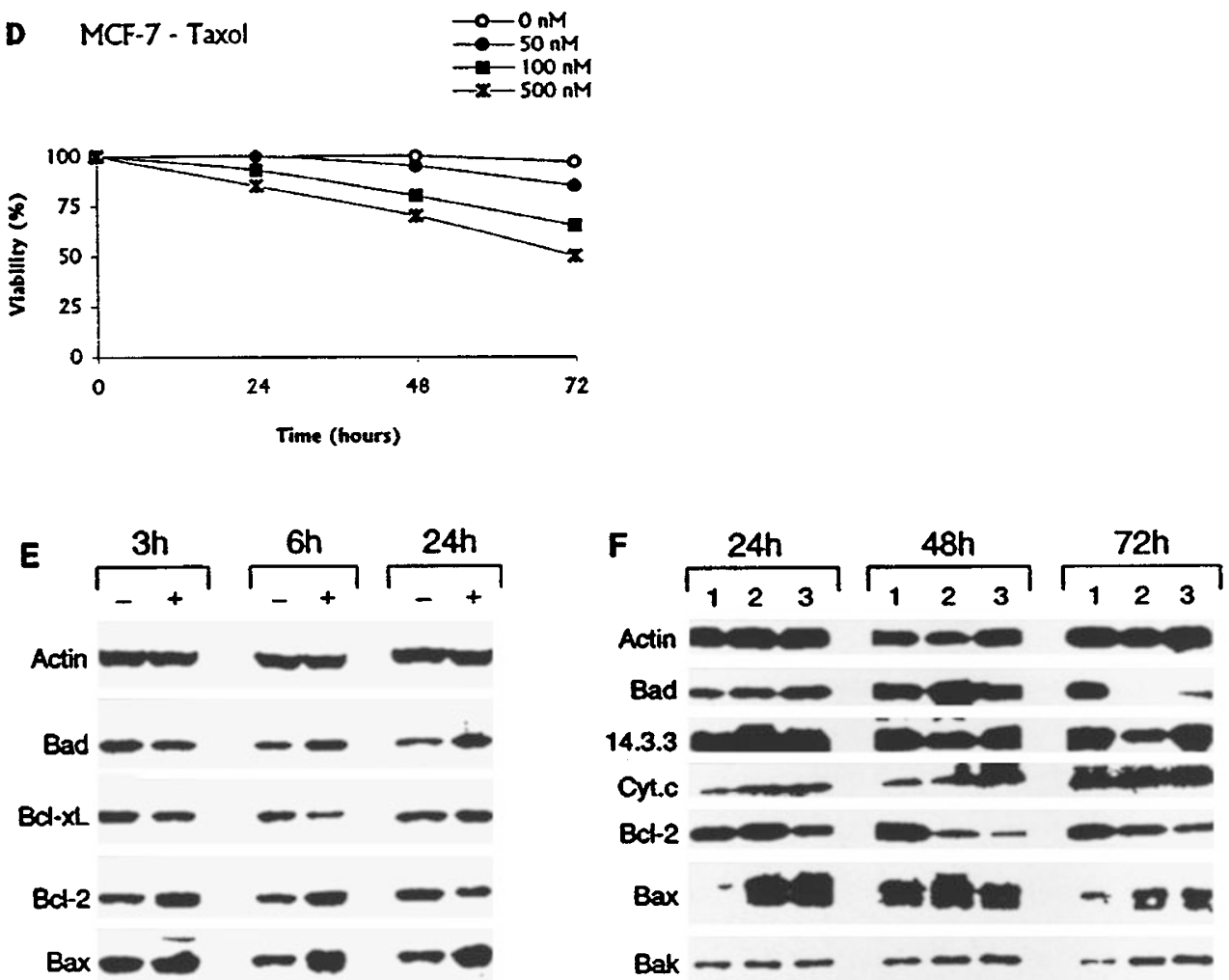

Figure 5 Expression and viability analysis of MCF-7 cells treated with Taxol. Total proteins ( $50 \mu \mathrm{g} / \mathrm{lane}$ ) from MCF-7 cells, either treated or not treated with Taxol for $0,3,6,24,48$ and $72 \mathrm{~h}$. The overall methodology is similar to Figure 2. The results shown are representative of three independent experiments. (A) Bad ( $\mathbf{\square})$ and

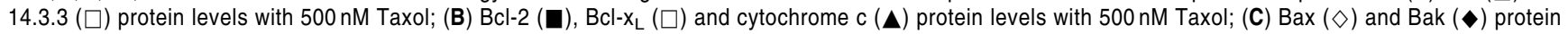
levels with $500 \mathrm{nM}$ Taxol; (D) Viability of the MCF-7 cells treated with 0,50, 100 and $500 \mathrm{nM}$ Taxol. Cells were collected at intervals, rinsed and scored for viability by Trypan blue staining. Triplicate samples were used for each treatment; (E) Cells were treated with (+) or without $(-) 500 \mathrm{nM}$ Taxol and aliquots, taken at intervals, were analyzed by immunoblot, as described; (F) Cells untreated (lane 1) or treated with $100 \mathrm{nM}$ (lane 2) or $500 \mathrm{nM}$ (lane 3) Taxol were analyzed by immunoblot, as described 
the complete processing of caspase-3 by $24 \mathrm{~h}$ (Figure 4D). Bax protein also shows a faster accumulation by $6 \mathrm{~h}$. This is in agreement with the higher rate of apoptosis at $24 \mathrm{~h}$ for the HL-60 cells treated with Thiotepa as compared to Taxol. The down-regulation of Bax by $48 \mathrm{~h}$, is accompanied by rapid accumulation of Bak, similar to the Taxol treated cells (Figure $4 \mathrm{H}$ ). We have not detected phosphorylated $\mathrm{Bcl}-2$ in response to Thiotepa treatment, which would suggest, as reported by others, that phosphorylated $\mathrm{Bcl}-2$ is a marker of $M$-phase events. Interestingly, the $B c l-x_{L}$ protein remains above the base-line level up to $48 \mathrm{~h}$ and the Bcl-2 level is also stable. This could account for the slower progression of apoptosis in the HL-60 cells treated with Thiotepa, at $48 \mathrm{~h}$, as compared to the MCF-7 cells or to the HL-60 cells treated with Taxol (Figure 1A,B).

An early increase in Bad and 14-3-3 protein levels was also detected in the MCF-7 cells treated with Taxol (Figure $5 A, E$ ), but to a lesser extent (twofold) than the increase detected in the HL-60 cells, and at a higher concentration of Taxol, $500 \mathrm{nM}$, which causes $85 \%$ cell survival at $24 \mathrm{~h}$ (Figure 5D). This might be related to the higher baseline level of Bad protein in these cells. At $72 \mathrm{~h}$ Bad protein level drops below the baseline level (Figure 4A,F) and this is paralleled by a similar reduction in mRNA level (Figure 3D).
A

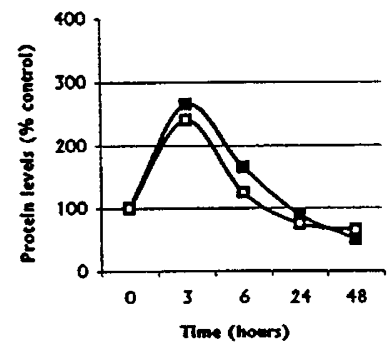

B

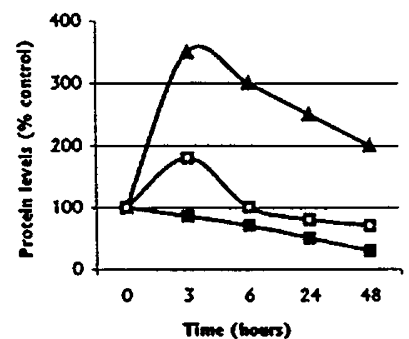

C

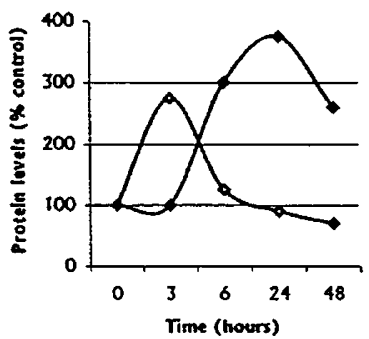

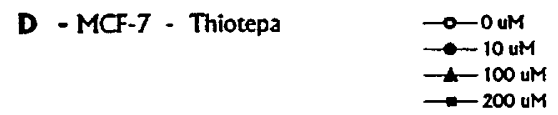
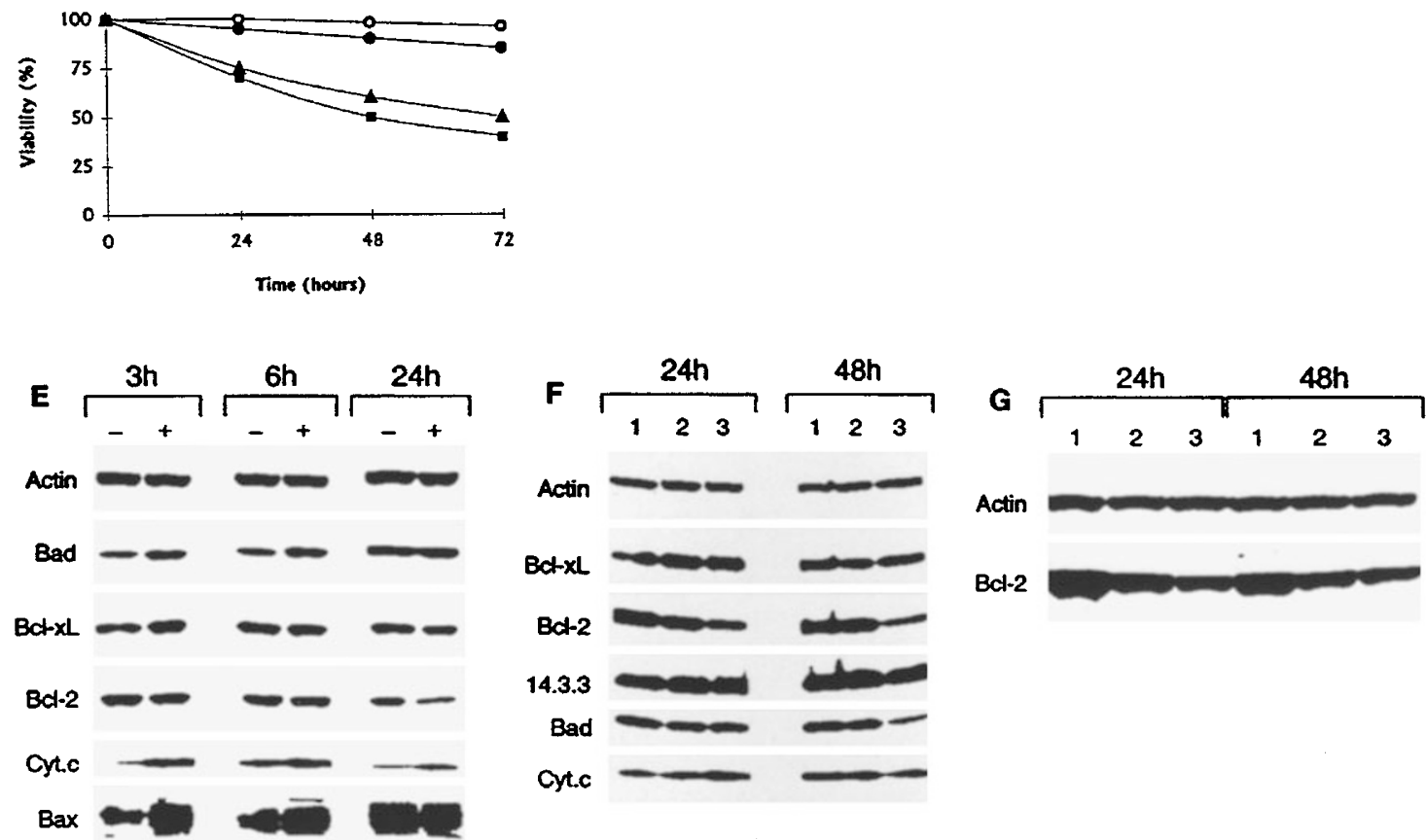

Figure 6 Expression and viability analysis of MCF-7 cells treated with Thiotepa. Total proteins ( $50 \mu \mathrm{g} / \mathrm{lane})$ from MCF-7 cells, either treated or not treated with Thiotepa for $0,3,6,24,48$ and $72 \mathrm{~h}$. The overall methodology is similar to Figure 2. The results shown are representative of three independent experiments. (A)

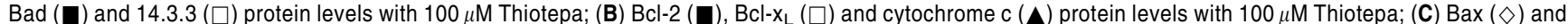

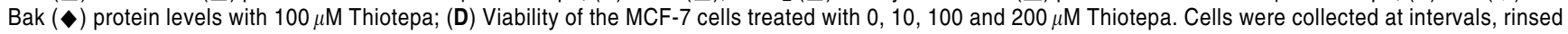
and scored for viability by Trypan blue staining. Triplicate samples were used for each treatment; (E) Cells were treated with $(+)$ or without $(-) 100 \mu \mathrm{M}$ Thiotepa and aliquots taken at intervals, were analyzed by immunoblot, as described; (F) Cells untreated (lane 1) or treated with $10 \mu \mathrm{M}$ (lane 2) or $100 \mu \mathrm{M}$ Thiotepa (lane 3) were analyzed by immunoblot, as described; (G) Cells untreated (lane 1) or treated with $100 \mu \mathrm{M}$ (lane 2) or $200 \mu \mathrm{M}$ (lane 3) Thiotepa were analyzed by immunoblot, as described 
Table 2. Bad protein expression in different tumor cell lines

\begin{tabular}{|c|c|c|c|c|c|c|}
\hline \multirow[b]{2}{*}{ Cell line } & \multicolumn{2}{|c|}{ Bad protein (\% control) ${ }^{a}$} & \multirow{2}{*}{$\begin{array}{c}\text { Drug conc. } \\
{[\mu \mathrm{M}]}\end{array}$} & \multicolumn{3}{|c|}{ Viability $(\%)^{\mathbf{b}}$} \\
\hline & $3 \mathrm{~h}$ & $6 \mathrm{~h}$ & & $3 \mathrm{~h}$ & $6 \mathrm{~h}$ & $24 \mathrm{~h}$ \\
\hline \multicolumn{7}{|l|}{ Leukemia } \\
\hline & & & Taxol & & & \\
\hline CEM & 85 & 90 & 0.1 & 97 & 90 & 40 \\
\hline SR & 100 & 175 & 0.025 & 86 & 70 & 60 \\
\hline RPMI & 100 & 180 & 0.1 & 90 & 85 & 70 \\
\hline MOLT-4 & 100 & 100 & 0.25 & 95 & 95 & 90 \\
\hline \multirow[t]{2}{*}{ K562 } & 150 & 220 & 0.25 & 95 & 92 & 90 \\
\hline & & & Thiotepa & & & \\
\hline CEM & 170 & 90 & 100 & 90 & 90 & 80 \\
\hline RPMI & 100 & 115 & 100 & 90 & 90 & 86 \\
\hline MOLT-4 & 100 & 160 & 100 & 95 & 90 & 80 \\
\hline K562 & 100 & 100 & 500 & 95 & 95 & 95 \\
\hline \multicolumn{3}{|c|}{ Breast carcinoma } & Taxol & & & \\
\hline T47-D & 135 & 75 & 0.5 & 95 & 95 & 75 \\
\hline MDA-231 & 135 & 75 & 0.5 & 90 & 85 & 70 \\
\hline BT549 & 180 & 80 & 0.5 & 95 & 80 & 70 \\
\hline MDA-MB-435 & 140 & 115 & 0.5 & 95 & 93 & 90 \\
\hline HS-578 & 280 & 160 & 0.025 & 85 & 75 & 60 \\
\hline MDA-N & 100 & 130 & 0.5 & 95 & 95 & 95 \\
\hline \multicolumn{3}{|c|}{ NSCLC (Non Small Cell Lung Carcinoma) } & Taxol & & & \\
\hline $\mathrm{H}-322$ & 135 & 240 & 2.5 & 98 & 98 & 90 \\
\hline $\mathrm{H}-226$ & 135 & 160 & 2.5 & 98 & 90 & 90 \\
\hline $\mathrm{H}-460$ & 75 & 80 & 2.5 & 95 & 90 & 80 \\
\hline
\end{tabular}

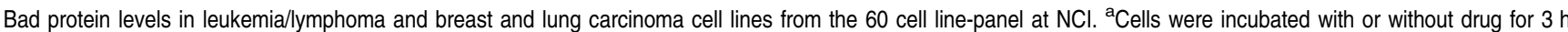
and $6 \mathrm{~h}$ and Bad protein levels were determined by immunoblot as described in Materials and Methods. The results are expressed as protein levels relative to untreated control (percentage of control). ${ }^{b}$ Cells were incubated with the indicated amounts of drug for $3 \mathrm{~h}$ and $6 \mathrm{~h}$ and the cell viability was assessed by Trypan blue staining

The increase in Bad at $6 \mathrm{~h}$ is followed by cytochrome $\mathrm{c}$ release, which is first detected at $24 \mathrm{~h}$. The delay in cytochrome $\mathrm{c}$ release is consistent with the idea that $\mathrm{Bcl}-2$ prevents the release of cytochrome $c$ from the mitochondria and inhibits apoptosis. In fact, Bcl-2 accumulates very early after exposure to Taxol and reaches a maximal level at $6 \mathrm{~h}$. Subsequently, the down-regulation of Bcl-2 at $24 \mathrm{~h}$, is accompanied by the release of cytochrome $c$, which reaches a peak at $48 \mathrm{~h}$ (Figure $5 B, E, F$ ). The release of cytochrome $\mathrm{C}$ is preceded by accumulation of Bax protein. There is no noticeable delay in the accumulation of Bax protein when compared to the HL-60 cells treated with Taxol, but the amplitude is higher. Again, Bax downregulation coincides with Bak accumulation (Figure 5C,F). We have not detected caspase-3 or the Bcl-2 cleavage product in the MCF-7 cells, even after prolonged exposure to high concentrations of Taxol. The phosphorylated Bcl-2 band is first seen at $24 \mathrm{~h}$. Our study shows that the early response to Taxol is delayed and blunted in the MCF-7 cells, with smaller increase in Bad protein levels and delayed cytochrome $c$ release. This is in agreement with the detection of apoptosis as late as $72 \mathrm{~h}$, when Bcl-2 and $\mathrm{BCl}-\mathrm{x}_{\mathrm{L}}$ levels are low and Bak levels are high.

In contrast to Taxol, the response of the MCF-7 cells to $100 \mu \mathrm{M}$ Thiotepa is very rapid, as shown by early detection of apoptosis (Figure 1) and only $75 \%$ viability at $24 \mathrm{~h}$ (Figure 6D). The early Bad induction ( $\leqslant 3 \mathrm{~h}$ ) (Figure $6 \mathrm{~A}, \mathrm{E}$ ) is again accompanied by a transient increase in 14-3-3 protein levels and followed by the release of cytochrome c. The up-regulation of Bax and the down-regulation of $\mathrm{Bcl}-2$ and $\mathrm{BCl}-\mathrm{x}_{\mathrm{L}}$ occur very early and, by $24 \mathrm{~h}$, both survival proteins are below baseline, whereas Bak levels are rapidly increasing (Figure 6B,C,E-G). This would explain the early apoptotic peak in these cells in response to Thiotepa.

We conclude that the early response to Taxol and Thiotepa treatment in both cell types consists of increased Bad expression, followed by cytochrome c release, Bcl-2 down-regulation and $\mathrm{Bcl}-\mathrm{x}_{\mathrm{L}}$ and Bax up-regulation. In both cell lines, with both drugs, the early events are similar, except for the delay seen in the MCF-7 cells in response to Taxol, in a way that correlates with $\mathrm{Bcl}-2$ accumulation and block of cytochrome $c$ release. The late increase in Bak is common to both cell lines. The delayed apoptosis of the MCF-7 cells in response to Taxol does not seem to be related to the absence of caspase- 3 in these cells, since the response of the MCF-7 cells to Thiotepa is very rapid, as shown by the early increase in cytoplasmic histonebound DNA fragments (Figure 1).

The time interval between $24-72 \mathrm{~h}$ for the MCF-7 cells treated with Taxol is strikingly similar to the interval between $3-24 \mathrm{~h}$ for the HL-60 cells treated with Taxol or Thiotepa and to the interval between $0-6 \mathrm{~h}$ for the MCF-7 cells treated with Thiotepa. These time intervals correspond to early events leading to apoptosis, which becomes evident only when both survival members, Bcl-2 and $\mathrm{Bcl}-\mathrm{x}_{\mathrm{L}}$ are down-regulated. $\mathrm{Bcl}-2$ and $\mathrm{Bcl}-\mathrm{x}_{\mathrm{L}}$ expression levels are reciprocal during these early time intervals. Similarly, Bax and Bak protein levels appear to be inversely correlated during the entire duration of drug treatment. 


\section{Bad protein expression in different cell lines in response to Taxol and Thiotepa treatment}

In order to see if these cytotoxic signals in other cancer cell types could also involve Bad, we looked at early Bad expression in 14 different cell lines belonging to the leukemia/lymphoma and breast sub-panels and certain lung carcinoma cell types in the $\mathrm{NCl}$ in vitro cell line cancer drug screen (Table 2). After Taxol treatment, three of five leukemia/ lymphoma cell lines show increased Bad expression at 3 or $6 \mathrm{~h}$ after treatment and sooner in the CEM cells; all breast carcinoma cells examined (six of six) also show some degree of Bad increase when examined at 3 or $6 \mathrm{~h}$ after drug exposure. All cell types retain viability during this period. In the case of Thiotepa, three of four leukemia/lymphoma cell lines show evidence of Bad increase during the same period after exposure to the agent, although in the case of RPMI the increase is minimal at $6 \mathrm{~h}$. It is further noteworthy that the magnitude or early timing of the Bad increase correlates in a general way with a greater reduction in viability at $24 \mathrm{~h}$.

\section{Discussion}

We hypothesized that different cellular responses leading to apoptosis might be evident in cell types exposed to different chemotherapeutic agents. We recognize that this response may or may not have involved changes in apoptotic regulatory protein levels, as there is no necessary reason to expect that such changes would be required for cell death. However, our results indicate that in two very different human cancer cell types (the MCF-7 breast carcinoma and the HL-60 myeloid leukemia cell lines), a qualitatively similar set of changes in apoptotic protein expression occurs after exposure to two agents with different mechanisms of action: Taxol, which stabilizes microtubules and Thiotepa, which is a DNA-directed alkylating agent. While the MCF-7 response to Taxol is greatly delayed and requires a higher drug concentration, analogous changes to those shown by the very sensitive HL-60 cells, are ultimately manifested.

Specifically, we have found that Bad protein increases at early times after drug exposure in both cell types, and this is accompanied by a similar increase in 14-3-3 protein. Our data demonstrate a coordinated increase in Bad and 14-3-3 proteins by $3 \mathrm{~h}$ after exposure to Taxol or Thiotepa in the HL-60 cells, or to Thiotepa in the MCF-7 cells, and a blunted and delayed response to Taxol in the MCF-7 cells. While we did not specifically assess phosphorylated Bad here, the coordinate increase in 14-3-3 with Bad suggests at least some level of signaling to Bad to promote downstream effects that will affect the survival of cells. Additionally, it is apparent that Bad mRNA also increases at a time when the cells are still largely viable, supporting the existence of regulation of either transcription or mRNA stability to promote Bad accumulation. This response appears to be temporally followed by increase in $\mathrm{Bcl}-\mathrm{X}_{\mathrm{L}}$ and decrease in $\mathrm{Bcl}-2$ levels at a time when $\mathrm{Bax}$ and cytochrome $\mathrm{c}$ are accumulating as an expression of mitochondrial injury and commitment to apoptosis. Again, the elevation of cytochrome $\mathrm{C}$ and $\mathrm{Bcl}-\mathrm{X}_{\mathrm{L}}$ appears delayed in Taxol-treated MCF-7 cells. Increase in Bak occurs as a relatively late event in both cell types in response to drug treatment. In the HL-60 (but not the MCF-7) cells, procaspase-3 is detected and evidence of processing occurs after cytochrome $c$ release. These events and their temporal sequence therefore focus attention on the early response of Bad to the toxic stimulus, as potentially a key regulator of downstream steps in the commitment to apoptosis. In support of this hypothesis, we also detect an early increase in Bad protein levels in different other breast and lung carcinoma and leukemia/lymphoma cell lines.

Bad is known to exist in a phosphorylated state in the cytoplasm, bound to 14-3-3, and a non-phosphorylated state at the mitochondrial surface, where it is hypothesized to antagonize the $\mathrm{Bcl}-2 / \mathrm{Bcl}-\mathrm{x}_{\mathrm{L}}$ survival function. ${ }^{13,45}$ The phosphorylated and non-phosphorylated forms of Bad might be involved in communicating transduced signals from the cytosol to the membrane-bound Bcl-2-like proteins, but the steps involved in the subcellular redistribution of Bad during apoptosis are not yet defined. It has been shown that phosphorylation of Bad by Akt results in its binding to $14-3-3$ in the cytosol, ${ }^{13,14}$ which would suggest that 14-3-3 might function as a protective element in preventing dephosphorylation of Bad and assure its transport to the mitochondria. Alternatively, the phosphorylation of Bad and its binding to 14-3-3 would allow its relocation to the cytosol and preclude its binding to $\mathrm{Bcl}-\mathrm{x}_{\mathrm{L}}$ in the mitochondrial membrane. Therefore, 14-3-3 might serve as a competitor of Bad, keeping it sequestered in the cytosol and preventing it from reaching the mitochondria. Since in our study, Bad mRNA increases in both cell-lines, we can further hypothesize as a result of these experiments that alteration of Bad transcription or mRNA stability is an early cellular response to stress or drug-induced injury. Furthermore, the increase in 14-3-3 level, would agree with the model suggesting that 14-3-3 associates with $\mathrm{Bad}$ at a pre-mitochondrial step. The evident injury to mitochondria through increase of detectable cytochrome $\mathrm{c}$ supports the participation of $\mathrm{Bad}$ in mitochondrial injury, as non-phosphorylated Bad, which binds to $\mathrm{BCl}-\mathrm{X}_{\mathrm{L}}$, thus freeing $\mathrm{BAX}$ and inducing apoptosis. This temporal sequence is also clearly supported by our data.

We notice that cytochrome $c$ release correlates inversely with the amount of $\mathrm{Bcl}-2$ protein in the cell, as might be expected if up-regulation of $\mathrm{Bcl}-2$ retards the release of cytochrome $\mathrm{c}$ and inhibits apoptosis. This is most clearly suggested by observations in the MCF-7 cells treated with Taxol but not in the same cells treated with Thiotepa and leads to the hypothesis that the timing plus the amount of cytochrome $c$ released might be good early indicators of the efficacy of a cytotoxic agent. We also notice that downregulation of $\mathrm{Bcl}-2$ is accompanied by increase of $\mathrm{Bcl}-\mathrm{x}_{\mathrm{L}}$. An inverse correlation between $\mathrm{Bcl}-2$ and $\mathrm{Bcl}-\mathrm{x}_{\mathrm{L}}$ persists during the early stages of the apoptotic pathway. The modulation of the cytochrome $c$ release would offer a rationale for the balance between the two survival proteins, which complement each other in the attempt to suppress death and this could result in a very fine control of the cytochrome $c$ release at the mitochondrial level. 
It has been shown that $\mathrm{Bcl}-\mathrm{x}_{\mathrm{L}}$ mRNA and protein levels increased in a variety of cells upon exposure to ionizing radiation (IR) and this was accompanied by Bax upregulation, ${ }^{7}$ suggesting that $\mathrm{Bcl}-\mathrm{x}_{\mathrm{L}}$ is an early response gene to genotoxic stress and apoptosis induced by IR through the p53-dependent pathway. Instead, we detect an increase in $\mathrm{Bcl}-\mathrm{x}_{\mathrm{L}}$ and Bax levels independently of the p53 status. Also, the up-regulation of Bax is accompanied by the downregulation of $\mathrm{Bcl}-2$. This would promote apoptotis as a result of decrease in the free homodimeric form of $\mathrm{Bcl}-2$ and an increase in the free, homodimeric form of Bax. Bax upregulation is more pronounced in the MCF-7 cells, which would be in agreement with the reports correlating it to the p53 status in the cells. ${ }^{46-48}$ It has been shown that the downregulation of $\mathrm{Bcl}-2 \mathrm{mRNA}$ and protein levels and the increase in Bax protein levels in the MCF-7 cells was associated with Basic Fibroblast Growth factor (bFGF)-induced apoptosis in these cells. ${ }^{49}$ Down-regulation of Bcl-2 mRNA and protein levels was also reported in connection with the induction of apoptosis in MCF-7 by sodium butyrate. ${ }^{50}$

We notice, as a later event, the down-regulation of Bax, which always coincides with a significant increase in Bak protein levels. The ability of Bax and Bak to induce cell death has been attributed to their heterodimerization with the death-suppressing Bcl-2 members. However, recent studies have shown that Bax and Bak do not necessarily require heterodimerization with $\mathrm{Bcl}-\mathrm{x}_{\mathrm{L}}$ and $\mathrm{Bcl}-2$ to promote cell death. ${ }^{51-53}$ We show that in both cell lines and both drugs, Bax and Bak show a very similar pattern of expression, independently of the $\mathrm{Bcl}-2$ and $\mathrm{Bcl}-\mathrm{x}_{\mathrm{L}}$ protein levels, which would suggest that some of their functions might not be dependent on dimerizations.

The presence of cytochrome $c$ in the cytosol has been reported to be necessary for activation of pro-caspases. Pro-caspase-9 and Apaf-1 (apoptotic protease activating factor 1) bind to each other via their respective $\mathrm{NH} 2$ terminal CED-3 homologous domains in the presence of cytochrome $\mathrm{c}$ and dATP, an event that leads to procaspase- 9 activation. Activated caspase- 9 in turn, cleaves and activates pro-caspase-3. ${ }^{54,55}$ It has been shown that Apaf-1 functions downstream of $\mathrm{Bcl}-2$, but upstream of caspase- 3 and that $\mathrm{Bcl}-2$ functions upstream of Apaf-1 by regulating the release of cytochrome $c$ from mitochondria. According to this hypothesis, overexpression of $\mathrm{Bcl}-2$, or its close family member $\mathrm{Bcl}-\mathrm{x}_{\mathrm{L}}$, blocks the release of cytochrome $\mathrm{c}$ from mitochondria. Our study shows that the activation of pro-caspase-3 occurs downstream from the

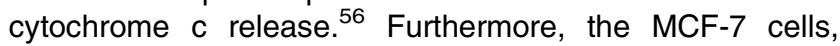
which have undetectable levels of caspase-3, show early and significant release of cytochrome $c$ in response to Thiotepa treatment.

The present experiments are phenomenological in nature and clearly do not address the mechanism underlying the very similar responses to very mechanistically different antiproliferative agents in two different cell types. The results presented here lead to the hypothesis that upregulation of Bad protein expression, which correlates with $\mathrm{Bcl}-2$ and $\mathrm{Bcl}-\mathrm{x}_{\mathrm{L}}$ protein levels, may be an important mediation of cellular response to anticancer agents, and is also found in different histologic types of tumor cells.
Bax increase, activation of caspases, post-transcriptional modifications of $\mathrm{Bcl}-2$ and finally Bak increase, represent clearly later steps. Our experiments also strikingly illustrate the general applicability of this pathway to two very different non-transfected or otherwise manipulated cell types (including wild-type and mutant p53 status) in response to drugs acting by different mechanisms. Further experiments will be of great interest in trying to understand the mechanisms leading to increase in Bad protein, and the manipulation of that response in modulating susceptibility to chemotherapeutic agents.

\section{Materials and Methods}

\section{Chemicals and cell culture}

Taxol (paclitaxel) (NSC-125973) and Thiotepa (NSC-6396) were obtained from the Drug Synthesis and Chemistry Branch, $\mathrm{NCl}$ Screen Program. Stock solutions were made in dimethyl sulfoxide, so that the highest concentration of DMSO used for cells treatment was less than $0.1 \%$. HL-60 promyelocytic and MCF-7 breast carcinoma cells were obtained from the $\mathrm{NCl}$ anticancer drug screen and grown in RPMI 1640 medium (Life Technologies, Grand Island, NY, USA) with 10\% FBS, $5 \mathrm{mM}$ L-Glutamine, $100 \mathrm{ng} / \mathrm{ml}$ penicillin and $100 \mathrm{ng} / \mathrm{ml}$ streptomycin at $37^{\circ} \mathrm{C}$ in $5 \% \mathrm{CO}_{2}$.

\section{Drug treatment}

Asynchronous and exponentially growing cells were treated with 0,10 , 50,100 and $500 \mathrm{nM}$ Taxol or with 0, 10, 100 and $200 \mu \mathrm{M}$ Thiotepa. Cells were collected after removal of the drugs, at $0,24,48$ and $72 \mathrm{~h}$ for long term and at $0,3,6$ and $24 \mathrm{~h}$ for short term time-course studies. Cells were then separated into aliquots and used for viability assay, protein and total RNA extraction.

\section{Apoptotic cell death and viability assays}

For the quantification of apoptotic cell death, we used a 'Cell Death Detection ELISA ${ }^{\text {PLUS' }}$ (Boehringer Mannheim, Indianapolis, IN, USA) that measures the cytoplasmic histone-bound DNA fragments (mono- and oligonucleosomes) generated during apoptosis. Briefly, $2 \times 10^{4}$ cells were plated into 96-well plates, in triplicates, and different concentrations of Taxol or Thiotepa were added for 0, 24, 48 and $72 \mathrm{~h}$. After drug treatment, plates were spun, washed and the pellets lysed according to the manufacturer. The enrichment of nucleosomes in the cytoplasm of treated cells was expressed as fold increase in apoptosis, compared to untreated cells. To evaluate the levels of cell death due to necrosis, triplicate control wells were set up, consisting in cells treated with $20 \mathrm{mM} \mathrm{KCN}$ for $4 \mathrm{~h}$, as described elsewhere. ${ }^{8}$ Positive controls for apoptosis consisted in triplicates of MCF-7 cells treated with $10 \mu \mathrm{M}$ Calcium lonophor A 23187 (Sigma) for $24 \mathrm{~h}$, and HL-60 cells treated with $150 \mathrm{nM}$ Camtothecin for $4 \mathrm{~h}$, respectively. The results represent three independent experiments and are expressed as fold increase relative to untreated cells.

For the viability assay, $2 \times 10^{6}$ cells were treated with $0,10,50,100$ and $500 \mathrm{nM}$ Taxol and 0,10,100 and $200 \mu \mathrm{M}$ Thiotepa and cell viability was assayed by trypan blue exclusion at $0,24,48$ and $72 \mathrm{~h}$. Triplicate samples were used for each treatment. 


\section{Western blot analysis}

Total proteins were isolated from $1-2 \times 10^{7}$ cells, lysed in $0.5-1 \mathrm{ml}$ lysis buffer (50 mM HEPES [pH 7.4]; $150 \mathrm{mM} \mathrm{KCl;} 5 \mathrm{mM} \mathrm{MgCl}_{2} ; 1 \mathrm{mM}$ EGTA; $0.5 \%$ NP-40; $0.5 \mathrm{mM}$ phenylmethylsulfonyl fluoride; $20 \mu \mathrm{M}$ leupeptine; $20 \mu \mathrm{M}$ aprotinin; $14 \mu \mathrm{M}$ pepstatin $\mathrm{A}$ ) by repeated freezing and thawing. Cell homogenates were centrifuged in an Eppendorf centrifuge at $4^{\circ} \mathrm{C}$, for $15 \mathrm{~min}$. Lysates for the immunodetection of cytochrome $c$ were prepared using the same lysis buffer, followed by quick mechanical disruption on ice, and spun at $14000 \times g$ for $30 \mathrm{~min}$ at $4^{\circ} \mathrm{C}$. Supernatants were removed and stored at $-70^{\circ} \mathrm{C}$, until analysis by gel electrophoresis. These lysates contained the cytosolic and light membrane fractions but not nuclei or mitochondria. Protein content in each lysate was determined by using the 'BCA Protein Assay' (Pierce, Rockford, IL, USA). Fifty $\mu \mathrm{g}$ of protein/lane were loaded on $12 \%$ Tris-glycine precast gels (Novex) and transferred in a submerged transfer unit (NOVEX Xcell II) to polyvynildifluoride (PVDF) membrane, in Tris-glycine transfer buffer (NOVEX) containing $5 \%$ methanol. Membranes were then blocked in TBS containing $0.1 \%$ Tween-20 and $10 \%$ dry milk, at room temperature for $1 \mathrm{~h}$ and used for immunoblotting. The following primary antibodies were used: $\mathrm{Bcl}-2$, 124 mouse monoclonal (Dako, Copenhagen, Denmark, \# MO887), Bax N-20 rabbit polyclonal (Calbiochem, \#PC66); $B c l-x_{L}$, rabbit polyclonal (Santa Cruz Biotechnology, Santa Cruz, CA, \#sc-634), $B A D$, rabbit polyclonal (Transduction Laboratories, \#B31420); Bak, mouse monoclonal (Pharmingen, \#65371); Caspase-3, rabbit polyclonal (Pharmingen, \#65906E); $\beta$-actin, mouse monoclonal (Sigma, \#A5441); Cytochrome $c$, mouse monoclonal (Pharmingen); 14-3-3 $\beta$ rabbit polyclonal (Santa Cruz Biotechnology, Santa Cruz, CA, \#sc-629). Immunoblotting was performed using $2-5 \mu \mathrm{g}$ of primary antibody and 1:2500 dilution of secondary antibody, in $10 \mathrm{ml}$ TBS containing $0.1 \%$ Tween 20 and $10 \%$ dry milk. Proteins were visualized using peroxidase-conjugated anti-mouse or anti-rabbit secondary antibodies and the ECL Western blotting detection reagents (Amersham, Arlington Heights, IL, USA) as recommended by the manufacturer. The resulting immunoblot signals were quantified by densitometric scanning (Digital Imaging System from Alpha Innotech Co.) The $\beta$-actin signal was used to normalize for the amount of protein loaded in each lane and the results were expressed as protein levels relative to untreated control (percentage of control).

\section{Isolation of total RNA and RT-PCR analysis}

Total RNA was isolated from $1 \times 10^{7}$ cells following treatment with different concentrations of drugs, by using the TRI REAGENT method (Molecular Research Center, Inc., Cincinnati, OH, USA). The reverse transcription (RT) reactions were done using the GeneAmp/RNA PCR reagents (Perkin Elmer \#N808-0017) on $5 \mu \mathrm{g}$ of DNAse treated total RNA, following the manufacturer's procedure. The resulting reverse transcribed product was divided into seven equal aliquots (for the seven sets of primers), in duplicate, and each sample was subsequently serially diluted in $1: 2,1: 5$ and $1: 10$. The primers were quantified prior to their use by agarose gel electrophoresis, ethidium bromide staining and densitometric scanning. Consistent amounts of primers and template were used for all experiments. The subsequent DNA amplification step was performed according to the manufacturer's recommendations, in a Perkin Elmer 9600 PCR machine $\left(95^{\circ} \mathrm{C}\right.$ for $45 \mathrm{~s}, 65^{\circ} \mathrm{C}$ for $45 \mathrm{~s}$ and $72^{\circ} \mathrm{C}$ for 2 min for 35 cycles). Amplification cycles were preceded by a denaturation step $\left(95^{\circ} \mathrm{C}\right.$ for $\left.2 \mathrm{~min}\right)$ and followed by an elongation step $\left(72^{\circ} \mathrm{C}\right.$ for $\left.10 \mathrm{~min}\right)$. The amplified products were analyzed on a $2 \%$ agarose gel by ethidium bromide staining and the signal was quantified by densitometric scanning (Digital Imaging System, Alpha Innotech
Co.). The following sets of primers were used: Bad forward: $5^{\prime}$ gagccgagtgagcaggaagac, Bad reverse: 5'-cactcatcctccggagctcgc; Bcl-x forward: 5'-cgggcattcagtgacctgac, Bcl-x reverse: 5-'tcaggaaccagcggttgaag; Bcl-2 forward: $5^{\prime}$-cgacttcgccgagatgtccagccag, Bcl-2 reverse: 5'-cttgtggctcagataggcacccagg; Bak forward: 5'-gtcctcccaggcaggagtgcggag, Bak reverse: 5'-gtcgaccacgaagcgggtcacctgg; Bax forward: $5^{\prime}$-cagctctgagcagatcatgaagaca, Bax reverse: $5^{\prime}$-gcccatcttcttccagatggtgagc; $\beta$-actin forward: 5 '-tgacggggtcacccacactgtgcccatcta, $\beta$ actin reverse: $5^{\prime}$-ctagaagcatttgcggtggacgatggaggg; $18 \mathrm{~S}$ forward: $5^{\prime}$ tcaagaacgaaagtcggagg, $18 \mathrm{~S}$ reverse: $5^{\prime}$-ggacatctaagggcatcaca. Twenty $\mu$ l of the final amplified DNA were run on $2 \%$ agarose gels, stained with ethidium bromide and the signal quantified by densitometric scanning. $\beta$-actin and $18 \mathrm{~S}$ amplified products were quantified and these values were used to normalize for the amount of template used in each reaction. The results are expressed as mRNA levels relative to untreated control (percentage of control).

\section{Acknowledgements}

This project has been funded with Federal funds from the National Cancer Institute, National Institute of Health, under Contract No. N01-C0-56000.

Disclaimer: The content of this publication does not necessarily reflect the views or policies of the Department of Health and Human Services, nor does mention of trade names, commercial products, or organizations implying endorsement by the US Government.

\section{References}

1. Reed JC (1997) Double identity for proteins of the Bcl-2 family. Nature 387: $773-$ 776

2. Hockenberry D, Nunez G, Milliman C, Schreiber RD and Korsmeyer SJ (1990) $\mathrm{Bcl}-2$ is an inner mitochondrial membrane protein that blocks programmed cell death. Nature 348: 334-336

3. Boise LH, Gonzales-Garcia M, Postema CE, Ding L, Lindsten T, Turka LA, Mao X, Nunez $\mathrm{G}$ and Thompson CB (1993) Bcl-x, a bcl-2-related gene that functions as a dominant regulator of apoptotic cell death. Cell 74: 597-608

4. Krajewski S, Tanaka S, Takayama S, Schibler MJ, Fenton W and Reed JC (1993) Investigations of the subcellular distribution of the bcl-2 oncoprotein: residence in the nuclear envelope, endoplasmic reticulum, and outer mitochondrial membranes. Cancer Res. 53: 4701-4714

5. Sato T, Hanada M, Bodrug S, Irie S, Iwama N, Boise LH, Thompson CB, Golemis E, Fong L, Wang HG and Reed JC (1994) Interactions among members of the bcl2 protein family analyzed with a yeast two-hybrid system. Proc. Natl. Acad. Sci. USA 91: $9238-9242$

6. Gonzalez-Garcia M, Perez-Ballestero R, Ding L, Duan L, Boise LH, Thompson CB and Nunez G (1994) Bcl-xL is the major Bcl-x mRNA form expressed during murine development and its product localizes to mitochondria. Development 120: $3033-3042$

7. Zhan Q, Alamo I, Yu K, Boise LH, Cherney B, Tosato G, O'Connor PM and Fornace AJ, Jr (1996) The apoptosis-associated gamma-ray response of $\mathrm{Bcl}-\mathrm{xL}$ depends on normal p53 function. Oncogene 13: 2287-2293

8. Shimizu S, Eguchi Y, Kamiike W, Waguri S, Uchiyama Y, Matsuda $H$ and Tsujimoto $Y$ (1996) Bcl-2 blocks loss of mitochondrial membrane potential while ICE inhibitors act at a different step during inhibition of death induced by respiratory chain inhibitors. Oncogene 13: 21-29

9. Kim CN, Wang X, Huang Y, Ibrado AM, Liu L, Fang G and Bhalla K (1997) Overexpression of $\mathrm{Bcl}-\mathrm{xL}$ inhibits ara-C-induced mitochondrial loss of cytochrome $c$ and other perturbations that activate the molecular cascade of apoptosis. Cancer Res. 57: 3115-3120

10. Yang J, Liu X, Bhalla K, Kim CN, Ibrado AM, Cai J, Peng TI, Jones DP and WangX (1997) Prevention of apoptosis by Bcl-2: release of cytochrome $\mathrm{c}$ from mitochondria blocked. Science 257: 1129-1132 
11. Yang E, Zha J, Jockel J, Boise LH, Thompson CB and Korsmeyer SJ (1995) Bad, a heterodimeric partner for $\mathrm{Bcl}-\mathrm{xL}$ and $\mathrm{Bcl}-2$, displaces Bax and promotes cell death. Cell 80: 285-291

12. Kelekar A, Chang BS, Harlan JE, Fesik SW and Thompson CB (1997) Bad is a $\mathrm{BH} 3$ domain-containing protein that forms an inactivating dimer with $\mathrm{Bcl}-\mathrm{xL}$. Mol. Cell Biol. 17: 7040-7046

13. Zha J, Harada H, Yang E, Jockel J and Korsmeyer J (1996) Serine phosphorylation of death agonist Bad in response to survival factor results in binding to 14.3.3 not Bcl-xL. Cell 87: 619-628

14. Datta SR, Dudek H, Tao X, Masters S, Fu HA, Gotoh Y and Greenberg ME (1997) Akt phosphorylation of Bad couples survival signals to the cell-intrinsic death machinery. Cell 91: 231-241

15. Chittenden T, Harrington EA, O'Connor R, Flemington C, Lutz RJ, Evan Gl and Guild BC (1995) Induction of apoptosis by the Bcl-2 homologue Bak. Nature 374: $733-736$

16. Oltvai ZN, Milliman CL and Korsmeyer S (1993) Bcl-2 heterodimerizes in-vivo with a conserved homologue, Bax, that accelerates programmed cell death. Cell 74: $609-619$

17. Manon S, Chaudhuri B and Guerin M (1997) Release of cytochrome c and decrease of cytochrome c oxidase in Bax-expressing yeast cells, and prevention of these effects by coexpression of Bcl-xL. FEBS Lett. 415: 29-32

18. Rosse T, Olivier R, Monney L, Rager M, Conus S, Fellay I, Jansen B and Borner $C$ (1998) Bcl-2 prolongs cell survival after Bax-induced release of cytochrome $\mathrm{C}$. Nature 391: 496-499

19. SedlakTW, Oltvai ZN, Yang E, Wang K, Boise LH, Thompson CB and Korsmeyer SJ (1995) Multiple Bcl-2 family members demonstrate selective dimerizations with Bax. Proc. Natl. Acad. Sci. USA 92: 7834-7838

20. Oltvai ZN and Korsmeyer SJ (1994) Checkpoint of dueling dimers foil death wishes. Cell 79: 189-192

21. Haldar S, Chintapalli J and Croce CM (1996) Taxol induces bcl-2 phosphorylation and death of prostate cancer cells. Cancer Res. 56: 1253-1255

22. Ito T, Deng XM, Carr B and May WS (1997) Bcl-2 phosphorylation required for anti-apoptosis function. J. Biol. Chem. 272: 11671-11673

23. May WS, Tyler PG, Ito T, Armstrong DK, Qatsha KA and Davidson NE (1994) Interleukin-3 and bryostatin-1 mediate hyper-phosphorylation of Bcl-2 in association with suppression of apoptosis. J. Biol. Chem. 269: 26865-26870

24. Haldar $\mathrm{S}$, Jena $\mathrm{N}$ and $\mathrm{Croce} \mathrm{CM}$ (1995) Inactivation of $\mathrm{Bcl}-2$ by phosphorylation. Proc. Natl. Acad. Sci. USA 92: 4507-4511

25. Scatena CD, Stewart ZA, Mays D, Tang LJ, Keefer CJ, Leach SD and Pietenpo JA (1998) Mitotic phosphorylation of Bcl-2 during normal cell cycle progression and Taxol-induced growth arrest. J. Biol. Chem. 273: 30777-30784

26. Ling YH, Tornos Cand Perez-Soler R(1998) Phosphorylation of Bcl-2 is a marker of $\mathrm{M}$ phase events and not a determinant of apoptosis. J. Biol. Chem. 273: $18984-18991$

27. Cheng EHY, Kirsch DG, Clem RJ, Ravi R, Kastan MB, Bedi A, Ueno K and Hardwich JM (1997) Conversion of Bcl-2 to a Bax-like death effector by caspases. Science 278: $1966-1968$

28. Thornberry NA and Lazebnik Y (1998) Caspases: enemies within. Science 281 $1312-1316$

29. Martin SJ and Green DR (1995) Protease activation during apoptosis: death by a thousand cuts? Cell 82: $349-352$

30. Li P, Nijhawan D, Budihardjo I, Srinivasula SM, Ahmad M, Alnemri ES and Wang X (1997) Cytochrome $c$ and dATP-dependent formation of Apaf-1/Caspase-9 complex initiates an apoptotic protease cascade. Cell 91: 479-489

31. Cohen NA, Egorin MJ, Snyder SW, Ashar B, Wietharn BE, Pan S, Ross D and Hilton $\mathrm{J}$ (1991) Interaction of $\mathrm{N}, \mathrm{N}^{\prime}, \mathrm{N}^{\prime \prime}$-triethylenethiophosphoramide and $\mathrm{N}, \mathrm{N}^{\prime}, \mathrm{N}^{\prime \prime}$-triethylenephosphoramide with cellular DNA. Cancer Res. 51: 4360 4366

32. Musser SM, Pan SS, Egorin MJ, Kyle DJ and Callery PS (1992) Alkylation of DNA with aziridine produced during hydrolysis of $\mathrm{N}, \mathrm{N}^{\prime}, \mathrm{N}^{\prime \prime}$-triethylenethiophosphoramide. Chem. Res. Toxicol. 5: 95-99

33. Schiff PB, Fant J and Horwiz SB (1979) Promotion of microtubule assembly in vitro by taxol. Nature $277: 665-667$

34. Liebmann JE, Cook JA, Lipschultz C, Teague D, Fisher J and Mitchell JB (1993) Cytotoxic studies of paclitaxel (Taxol) in human tumour cell lines. Br. J. Cancer 68: $1104-1109$

35. Lopez NM, Adams EG, Pitts TW and Bhuyan KB (1993) Cell kill kinetics and cell cycle effects of taxol on human and hamster ovarian cell lines. Cancer Chemother. Pharmacol. 32: 235-242
36. Woods CM, Zhu J, McQueney PA, Bollag D and Lazarides E (1995) Taxolinduced mitotic block triggers rapid onset of a p53-independent apoptotic pathway. Molecular Medicine 1:506-526

37. Wahl AF, Donaldson KL, Fairchild C, Lee FYF, Foster SA, Demers GW and Galloway DA (1996) Loss of normal p53 function confers sensitization to Taxol by increasing G2/M arrest and apoptosis. Nature Med. 2: $72-79$

38. Barboule N, Chadebech P, Baldin V, Vidal S and Valette A (1997) Involvement of p21 in mitotic exit after paclitaxel treatment in MCF-7 breastadenocarcinoma cell line. Oncogene 15: 2867-2875

39. Lee LF, Li G, Templeton DJ and Ting JP (1998) Paclitaxel (Taxol)-induced gene expression and cell death are both mediated by the activation of c-Jun NH2terminal Kinase (JNK/SAPK). J. Biol. Chem. 273: 28253-28260

40. Lieu CH, Liu CC, Yu TH, Chen KD, Chang YN and Lai YK (1998) Role of mitogenactivated protein kinase in taxol-induced apoptosis in human leukemic U937 cells. Cell Growth Differ. 9: 767-775

41. Blagosklonny MV, Schulte T, Nguyen P, Trepel J and Neckers LM (1996) Taxolinduced apoptosis and phosphorylation of Bcl-2 protein involves c-Raf-1 and represents a novel c-Raf-1 signal transduction pathway. Cancer Res. 56: 1851 1854

42. Moos PJ and Fitzpatrick FA (1998) Taxane-mediated gene induction is independent of microtubule stabilization: induction of transcription regulators and enzymes that modulate inflammation and apoptosis. Proc. Natl. Acad. Sci. USA 95: 3896-3901

43. Ling YH, Consoli U, Tornos C, Andreeff M and Perez-Soler R (1998) Accumulation of Cyclin B1, activation of Cyclin B1-dependent kinase and induction of programmed cell death in human epidermoid carcinoma KB cells treated with Taxol. Int. J. Cancer 75: 925-932

44. Amato SF, Swart JM, Berg M, Wanebo HJ, Mehta SR and Chiles TC (1998) Transient stimulation of the c-Jun-NH2-terminal kinase/activator protein 1 pathway and inhibition of extracellular signal-regulated kinase are early effects in paclitaxel-mediated apoptosis in human B lymphoblasts. Cancer Res. 58: 241 247

45. Zha J, Harada H, Osipov K, Jockel J, Waksman G and Korsmeyer SJ (1997)BH3 domain of Bad is required for heterodimerization with $\mathrm{Bcl}-\mathrm{xL}$ and pro-apoptotic activity. J. Biol. Chem. 272: 24101-24104

46. Selvakumaran M, Lin HK, Miyashita T, Wang HG, Krajewski S, Reed JC, Hoffman B and Liebermann D (1994) Immediate early up-regulation of bax expression by 53 butnot TGF beta 1: a paradigm for distinct apoptotic pathways. Oncogene 9: 1791-1798

47. Zhan Q, Fan S, Bae I, Guillouf C, Liebermann DA, O'Connor PM and Fornace AJ Jr (1994) Induction of bax by genotoxic stress in human cells correlates with normal p53 status and apoptosis. Oncogene 9: 3743-3751

48. Miyashita T and Reed TC (1995) Tumor suppressor p53 is a direct transcriptiona activator of the human bax gene. Cell 80: 293-299

49. Wang Q, Maloof P, Wang H, Fenig E, Stein D, Nichols G, Denny TN, Yahalom J and Wieder R (1998) Basic fibroblast growth factor downregulates Bcl-2 and promotes apoptosis in MCF-7 human breast cancer cells. Experimental Cell Research 238: 177-187

50. Mandal M and Kumar R (1996) Bcl-2 expression regulates sodium butyrateinduced apoptosis in human MCF-7 breast cancer cells. Cell Growth Differ. 7: $311-318$

51. Simonian PL, Grillot DA and Nunez G (1997) Bak can accelerate chemotherapyinduced cell death independently of its heterodimerization with $\mathrm{Bcl}-\mathrm{xL}$ and Bcl-2. Oncogene 15: 1871-1875

52. Simonian PL, Grillot DA, Merino R and Nunez G (1996) Bax can antagonize Bc$\mathrm{XL}$ during etoposide and cisplatin-induced cell death independently of its heterodimerization with Bcl-xL. J. Biol. Chem. 271: 22764-22772

53. Zha H and Reed JC (1997) Heterodimerization-independent functions of cell death regulatory proteins Bax and Bcl-2 in yeast and mammalian cells. J. Biol. Chem. 272: 31482-31488

54. Liu X, Kim CN, Yang J, Jemmerson R and Wang X (1996) Induction of the apoptotic program in cell-free extracts: requirement for dATP and cytochrome $c$. Cell 86: 147-157

55. Cardone MH, Roy N, Stennicke HR, Salvesen GS, Franke TF, Stanbridge E, Frisch S and Reed JC (1998) Regulation of cell death protease Caspase-9 by phosphorylation. Science 282: 1318-1321 
56. Bossy-WetzelE, NewmeyerDD and Green DR (1998) Mitochondrial cytochrome c release in apoptosis occurs upstream of DEVD-specific caspase activation and independently of mitochondrial transmembrane depolarization. EMBO J. 17 $37-49$

57. Kitada S, Krajewska M, Zhang X, Scudiero D, Zapata JM, Wang HG, Shabaik A Tudor G, Krajewski S, Myers TG, Johnson GS, Sausville EA and Reed JC (1998) Expression and localization of pro-apoptotic $\mathrm{Bcl}-2$ family protein Bad in normal human tissues and tumor cell lines. Am. J. Path. 152: 51-61

58. O'Connor PM, Jackman J, Bae I, Myers TG, Fan S, Mutoh M, Scudiero DA Monks A, Sausville EA, Weinstein JN, Friend S, Fornace Jr A and Kohn KW (1997) Characterization of the p53 tumor suppressor pathway in cell lines of the National Cancer Institute Anticancer Drug Screen and correlations with the growth-inhibitory potency of 123 anticancer agents. Cancer Res. 57: 42854300
59. Monks A, Scudiero D, Skehan P, Shoemaker R, Paull K, Vistica D, Hose C, Langley J, Cronise P, Vaigro-Wolff A, Gray-Goodrich M, Campbell H, Mayo J and Boyd M (1991) Feasibility of a high-flux anticancer drug screen using a diverse panel of cultured human tumor cell lines. J. Natl. Cancer Inst. 83: 757-766 